https://helda.helsinki.fi

Four new Micarea species from the montane cloud forests of Taita Hills, Kenya

Kantelinen, Annina

2021-01

Kantelinen , A , Hyvärinen , M , Kirika , P \& Myllys , L 2021, ' Four new Micarea species from the montane cloud forests of Taita Hills, Kenya ', Lichenologist , vol. 53 , no. 1 , pp. 81-94 . https://doi.org/10.1017/S0024282920000511

http://hdl.handle.net/10138/329202

https://doi.org/10.1017/S0024282920000511

cc_by_nc_nd

acceptedVersion

Downloaded from Helda, University of Helsinki institutional repository.

This is an electronic reprint of the original article.

This reprint may differ from the original in pagination and typographic detail.

Please cite the original version. 
Author's accepted manuscript

The Lichenologist, 1/2021

\title{
Four new Micarea species from the montane cloud forests of Taita Hills, Kenya
}

\author{
Annina Kantelinen ${ }^{1}$, Marko-Tapio Hyvärinen ${ }^{1}$, Paul M. Kirika² and Leena Myllys ${ }^{1}$ \\ ${ }^{1}$ Botany Unit, Finnish Museum of Natural History, P.O. Box 7, FI-00014 University of Helsinki, Finland; ${ }^{2}$ East African \\ Herbarium, National Museums of Kenya, P.O. Box 40658, 00100 Nairobi, Kenya \\ Author for correspondence: Annina Kantelinen (former Launis). E-mail: annina.kantelinen@ helsinki.fi
}

\begin{abstract}
The genus Micarea was studied for the first time in the Taita Hills, Kenya. Based on new collections and existing data, we reconstructed a phylogeny using ITS, mtSSU and Mcm7 regions, and generated a total of 27 new sequences. Data were analyzed using maximum likelihood and maximum parsimony methods. Based mainly on new collections, we discovered four undescribed well-supported lineages, characterized by molecular and phenotypic features. These lineages are described here as Micarea pumila, M. stellaris, M. taitensis and M. versicolor. Micarea pumila is characterized by a minutely granular thallus, small cream-white or pale brownish apothecia, small ascospores and the production of prasinic acid. Micarea stellaris has a warted-areolate thallus, cream-white apothecia usually darker at the centre, a hymenium of light grey or brownish pigment that dissolves in $\mathrm{K}$, and intense crystalline granules that appear as a belt-like continuum across the lower hymenium when studied in polarized light. Micarea taitensis is characterized by a wartedareolate thallus and pale cream or yellowish apothecia that sometimes produce the Sedifolia-grey pigment. Micarea versicolor is characterized by a warted-areolate, sometimes partly granular thallus and apothecia varying from cream-white to light grey to blackish in colour. This considerable variation in the coloration of its apothecia is caused by an occasional mixture of the Sedifolia-grey pigment in the epihymenium and another purplish brown pigment in the hymenium. Micarea stellaris, $M$. taitensis and $M$. versicolor produce methoxymicareic acid. The main distinguishing characters are presented in a species synopsis. Three of the new species are nested in the M. prasina group, and the fourth one (M. taitensis) resolves as a basal taxon to the $M$. prasina group. The new species inhabit montane cloud forests, which have fragmented dramatically throughout the Eastern Arc Mountains in recent decades.
\end{abstract}

Key words: biodiversity hotspot, Eastern Arc Mountains, endemism, lichens, molecular phylogenetics, taxonomy

\section{Introduction}

The Taita Hills are part of the Eastern Arc Mountains that range from south-eastern Kenya to eastern Tanzania. The montane cloud forests of this area are known for their high degree of biodiversity and endemism, and they are recognized as one of the biodiversity hotspots of the world (Rogo \& Oguge 2000; Burgess et al. 2006; Lange 2006; Malonza et al. 2010). This rich and unique ecosystem is an outcome of long isolation as well as favourable climatic conditions. The mountains rise abruptly from the surrounding plain and native vegetation effectively captures precipitation from clouds and mist developed by the relatively cool air rising from the Indian Ocean.

The forests in the Taita Hills are influenced considerably by human action and have become highly fragmented. The remaining indigenous forests are mainly found on the hilltops and 
continue to shrink year by year. According to Pellikka et al. (2009), the total area of indigenous forest diminished by 50\% between 1955 and 2004. Today, the largest remaining indigenous forests are on the mountains of Mbololo (220 ha), Ngangao (124 ha) and Chawia (50 ha) (Burgess et al. 2006; Rogers et al. 2008; Pellikka et al. 2009). The total forest area of the Taita Hills has, however, only reduced by $2 \%$. This is due to exotic forest plantations that have replaced large areas of the indigenous forest comprising Acacia mearnsii, Cupressus lusitanica, Eucalyptus saligna and Pinus patula stands growing side by side, or even intermixed with natural forests. Planted forests are usually less efficient in capturing moisture and more susceptible to forest fires and, therefore, may permanently change the whole ecosystem towards a drier one (Pellikka et al. 2009)

Following on from several historical works (e.g. Zahlbruckner 1926; Cengia Sambo 1938; Santesson 1952; Maas Geesteranus 1955; Klement 1962), a critical and comprehensive study of lichens in East Africa including Kenya was conducted by Swinscow \& Krog (1988), and their work has since been continued by several authors (e.g. Farkas 1987; Farkas \& Vězda 1993; Jørgensen 1994; Kalb \& Vězda 1994; Frisch \& Hertel 1998; Frisch 1999; Marbach 2000; Lücking \& Kalb 2002; Alstrup \& Aptroot 2005; Alstrup \& Christensen 2006; Yeshitela 2008; Yeshitela et al. 2009; Rikkinen 2010; Kirika et al. 2012; Farkas \& Flakus 2015; Bjelland et al. 2017; Suija et al. 2018). However, the genus Micarea Fr., with over 100 species known worldwide (International Mycological Association 2019), is largely overlooked in Africa (but see Coppins 1999; Brand et al. 2014) and its species have not been collected in the Taita Hills until now. In Australasia, Europe and the Russian Far East, the taxonomy and systematics of the genus has recently received much scientific interest (e.g. Czarnota 2007; van den Boom et al. 2017; Guzow-Krzemińska et al. 2019; Kantvilas \& Coppins 2019; Konoreva et al. 2019; Launis et al. 2019a, b).

Recent molecular phylogenies show that Micarea is paraphyletic (Andersen \& Ekman 2005; Sérusiaux et al. 2010), even after the introduction of the new genera Brianaria S. Ekman \& M. Svensson for the M. sylvicola group (Ekman \& Svensson 2014) and Leimonis Harris \& Lendemer for the $M$. erratica group (Harris 2009). The $M$. prasina group, which includes the type species $M$. prasina Fr., forms a monophyletic core group in the genus. The group is characterized by a 'micareoid' photobiont (a coccoid green alga with cells of 4-7.5 $\mu \mathrm{m}$ diam.), immarginate small apothecia, a hyaline hypothecium, branched paraphyses, and an ascus of the Micarea type, with a $\mathrm{K} / \mathrm{I}+$ blue amyloid tholus and a more lightly staining axial body often with a darkly stained lining (Hafellner 1984; Czarnota 2007; Ekman et al. 2008). Many species develop effuse thalli composed of goniocysts and produce Sedifolia-grey pigment ( $\mathrm{K}+$ violet, $\mathrm{C}+$ violet $)$, which is typically present in the epihymenium of the apothecia as well as the pycnidia (Coppins 1983; Czarnota \& GuzowKrzemińska 2010).

In this study, we explored the diversity and systematics of Micarea species in the Taita Hills of Kenya. We used phenotypic characters and molecular DNA sequence data from three loci (nuclear rDNA internal transcribed spacer region (ITS1-5.8S-ITS2 = ITS), mitochondrial rDNA small subunit (mtSSU) and replication licensing factor $M c m 7$ ). We also continued to investigate the use of crystalline granules as a character for species delimitation (Guzow-Krzemińska et al. 2019; Launis et al. 2019a,b). The focus of this study was the epiphytic and epixylic Micarea species in indigenous and planted forests of the two mountains, Ngangao and Vuria. This study increases our knowledge of the diversity of lichens in the Taita Hills, and also reveals the suitability of plantation forest habitats for Micarea species. 


\section{Material and Methods}

\section{Taxon sampling}

Fresh specimens were collected on the mountains of Ngangao (c. $1952 \mathrm{~m})$ and Vuria $(2228 \mathrm{~m})$ in Kenya, during an expedition in 2017. According to Pellikka et al. (2009), the intensity of human disturbance in the Ngangao forests is moderate, whereas it is relatively higher in Vuria, where only 1 ha of indigenous forest remains (Wilder et al. 1998). Type material of related Micarea species from the herbaria H-NYL and UPS were studied for comparison. The samples used in phylogenetic analyses are listed in Table 1 and include a total of 52 specimens of 42 taxa.

\section{DNA extraction, polymerase chain reaction and DNA sequencing}

Genomic DNA was extracted from 1-3 apothecia of specimens stored for a maximum of 1 year, using the DNeasy Blood \& Tissue Kit (Qiagen, Maryland, USA) following the protocol described by Myllys et al. (2011). Polymerase chain reactions (PCRs) were prepared using PuReTaq ReadyTo- Go PCR Beads (GE Healthcare, Chicago, Illinois, USA). Each $25 \mu 1$ reaction volume contained $19 \mu \mathrm{l}$ distilled water $(\mathrm{dH} 2 \mathrm{O}), 1 \mu \mathrm{l}$ of each primer $(10 \mu \mathrm{M})$, and $4 \mu \mathrm{l}$ extracted DNA. The primers listed below were used for PCR amplification and sequencing.

For the ITS region, PCR was run under the following conditions: initial denaturation for 5 min at $95{ }^{\circ} \mathrm{C}$ followed by five cycles of $30 \mathrm{~s}$ at $95{ }^{\circ} \mathrm{C}$ (denaturation), $30 \mathrm{~s}$ at $58^{\circ} \mathrm{C}$ (annealing), and $1 \mathrm{~min}$ at $72{ }^{\circ} \mathrm{C}$ (extension); for the remaining 40 cycles, the annealing temperature was decreased to $56{ }^{\circ} \mathrm{C}$; the PCR program ended with a final extension for $7 \mathrm{~min}$ at $72{ }^{\circ} \mathrm{C}$. The primers used were ITS1-LM (Myllys et al. 1999) and ITS4 (White et al. 1990).

For the mtSSU gene, PCR was run under the following conditions: initial denaturation for 10 min at $95{ }^{\circ} \mathrm{C}$ followed by six cycles of $1 \mathrm{~min}$ at $95^{\circ} \mathrm{C}$ (denaturation), $1 \mathrm{~min}$ at $62{ }^{\circ} \mathrm{C}$ (annealing), and $1 \mathrm{~min} 45 \mathrm{~s}$ at $72{ }^{\circ} \mathrm{C}$ (extension); for the remaining 35 cycles, the annealing temperature was decreased to $56{ }^{\circ} \mathrm{C}$; the PCR program ended with a final extension of $10 \mathrm{~min}$ at $72{ }^{\circ} \mathrm{C}$. The primers used were mrSSU1 and mrSSU3R (Zoller et al. 1999).

For the $\mathrm{Mcm} 7$ gene, PCR was run under two different conditions depending on the primers selected. For the first protocol, an initial denaturation for $10 \mathrm{~min}$ at $94{ }^{\circ} \mathrm{C}$ was followed by 38 cycles of $45 \mathrm{~s}$ at $94{ }^{\circ} \mathrm{C}$ (denaturation), $50 \mathrm{~s}$ at $55^{\circ} \mathrm{C}$ (annealing), and $1 \mathrm{~min}$ at $72{ }^{\circ} \mathrm{C}$ (extension), with the PCR program ending with a final extension for $5 \mathrm{~min}$ at $72{ }^{\circ} \mathrm{C}$. The primers used were MCM7_AL1r and MCM7_AL2f (Launis et al. 2019a). The second protocol used an initial denaturation for $10 \mathrm{~min}$ at $94{ }^{\circ} \mathrm{C}$, followed by 38 cycles of $45 \mathrm{~s}$ at $94{ }^{\circ} \mathrm{C}$ (denaturation), $50 \mathrm{~s}$ at $56{ }^{\circ} \mathrm{C}$ (annealing), and $1 \mathrm{~min}$ at $72{ }^{\circ} \mathrm{C}$ (extension); the PCR program ended with a final extension for $5 \mathrm{~min}$ at $72{ }^{\circ} \mathrm{C}$. The primers used were x.Mcm7.f (Leavitt et al. 2011) and Mcm7.1348R (Schmitt et al. 2009).

PCR products were cleaned and sequenced by Macrogen Inc. (Amsterdam, The Netherlands; www.macrogen.com).

\section{Phylogenetic analyses}

In order to examine the phylogenetic position of our study species within Micarea s. lat., we made a preliminary analysis of a combined mtSSU $+M c m 7$ data set using Psora decipiens (Hedw.) Hoffm. from the family Psoracaeae as an outgroup, based on a study by Andersen \& Ekman (2005). ITS regions were too variable and could not be included in the analysis. In the phylogeny (tree not shown) our new samples fall within the Micarea prasina group as delimited by van den Boom et al. (2017), Launis \& Myllys (2019), Launis et al. (2019a, b) and Guzow-Krzemińska et al. (2019), except for one specimen, $M$. taitensis sp. nov., which appears as basal to the $M$. prasina group.

The final phylogenies comprising $33 \mathrm{ITS}, 52 \mathrm{mtSSU}$ and $40 \mathrm{Mcm} 7$ sequences were first aligned separately with MUSCLE v.3.8.31 (Edgar 2004) using the European Molecular Biology Laboratory, European Bioinformatics Institute's (EMBL-EBI) freely available web server 
(http://www.ebi.ac.uk/Tools/msa/muscle/). Phylogenetic analyses for each gene region were performed as below for the concatenated data set. The single gene trees did not show any strongly supported conflicts according to the approach of Kauff \& Lutzoni (2002) (with threshold bootstrap values $\geq 75 \%$ ) and the three data sets were combined into a concatenated matrix in PhyDE® (Phylogenetic Data Editor, http://www.phyde.de/index.html). Based on our previous studies (Launis et al. 2019a, b) and our preliminary phylogenetic reconstruction, Micarea peliocarpa (Anzi) Coppins \& R. Sant. was used as an outgroup. The hypervariable region at the end of the mtSSU and the ambiguously aligned region at the end of the ITS2 were removed from the analyses. The concatenated data set, including 52 terminals, was subjected to maximum parsimony (MP) analysis as implemented in TNT v.1.1 (Goloboff et al. 2008) and to maximum likelihood (ML) analysis using RAxML 8.1.15 (Stamatakis 2014) on the CSC-IT Center for Science server (http://www.csc.fi/home). The MP analysis was performed using 'traditional search' with random addition of sequences with 100 replicates and the tree bisection reconnection (TBR) branch swapping algorithm. Ten trees were saved for each replicate and gaps were treated as missing data. Node support was estimated by bootstrapping (Felsenstein 1985) with 1000 replicates. Bootstrap values $>75 \%$ were considered significant. For the ML analysis, the combined data set was assigned to seven partitions: ITS1, 5.8S, ITS2, mtSSU, and each of three codon positions of $\mathrm{Mcm} 7$. An independent GTR + G model was used for each subset, and branch lengths were assumed to be proportional across subsets. Node support was estimated with 1000 bootstrap replicates using the rapid bootstrap algorithm. The alignments are available from the Dryad Digital Repository (https://doi.org/10.5061/dryad.vmcvdncqv).

\section{Morphology and chemistry}

Hand-cut apothecial sections and squashed thallus preparations were examined with a dissecting and compound microscope. Ascospores and other anatomical details were studied and measurements made on material mounted in water or in $10 \%$ potassium hydroxide $(\mathrm{K})$ to relax features. Measurements are given in the format of minimum and maximum values. Rare minimum or maximum measurements of ascospores are given in parentheses. Chemical spot tests were performed under a compound microscope using sodium hypochlorite (C) and K (Orange et al. 2010). Pigments were defined following Coppins (1983), Meyer \& Printzen (2000) and Czarnota (2007). The chemistry of the samples was further studied using thin-layer chromatography (TLC) in solvent system ' $C$ ', following Culberson \& Kristinsson (1970) and Orange et al. (2010). The crystalline granules were investigated using a compound microscope with polarization filters.

\section{Results}

The multilocus data matrix from sequences of 52 specimens included 1793 aligned nucleotide characters, with 776 positions in the mtSSU, 592 positions in the $\mathrm{Mcm} 7$ gene and 425 positions in the ITS regions. Since the topologies of the ML and MP analyses did not have any strongly supported conflicts, only the tree obtained from the ML analysis is shown (Fig. 1).

The highly resolved phylogeny agrees with that already presented in earlier studies (GuzowKrzemińska et al. 2016; van den Boom et al. 2017; Launis \& Myllys 2019; Launis et al. 2019a, b). However, it should be noted that our new accessions of Micarea eximia Hedl. form a basal clade in the phylogeny after $M$. incrassata Hedl., and the $M$. eximia sequence obtained from GenBank groups instead with $M$. misella (Nyl.) Hedl. Our sequences of M. eximia are extracted from reliably identified specimens collected in 2015 from central Finland, and the species has been collected several times since. Micarea eximia is a rarely collected species and most of the specimens are from Fennoscandia and northern Scotland. The GenBank accession is most probably obtained from an undescribed species or is a sequence of $M$. misella. A North American species, M. endocyanea 
(Tuck. ex Willey) R. C. Harris, is analyzed here for the first time and is closely related to $M$. elachista (Körb.) Coppins \& R. Sant. The species has a darkly pigmented hypothecium, which is a rare exception amongst its relatives.

The Micarea prasina group is strongly supported (97\%) and a clade including $M$. tomentosa Czarnota \& Coppins and M. pusilla Launis et al. appears as basal. The remaining taxa of the $M$. prasina group are divided into two clades: the first, strongly supported clade (99\%) includes $M$. hedlundii Coppins, M. xanthonica Coppins \& Tønsberg and species referred to the M. byssacea and M. micrococca complexes (see Czarnota \& Guzow-Krzemińska 2010; Launis et al. 2019a); the second clade remains unsupported and consists of species from the $M$. prasina complex (see Launis et al. 2019b).

Our new material was found in four separate lineages and is supported by unique molecular and phenotypic characters. The main distinguishing morphological characters are presented in a species synopsis (Table 2). Micarea stellaris sp. nov., represented by one specimen in our phylogeny, is nested in the $M$. micrococca complex and forms a strongly supported clade with $M$. levicula (Nyl.) Coppins (a specimen collected from the island of Réunion by Brand et al. (2014)). Micarea versicolor sp. nov., including four specimens, and $M$. pumila sp. nov. with one specimen are both members of the $M$. prasina complex. The two species form a strongly supported group but are separated from each other by rather long branches and also from other members of the complex. The fourth new species discovered in our study, M. taitensis sp. nov., appears as a basal taxon to the M. prasina group.

Small crystalline granules, soluble in $\mathrm{K}$, were studied in polarized light and are shown in detail in Fig. 3. The granules were detected in the hymenium of all four new species. In M. stellaris, the granules appear as an intense belt-like continuum across the lower hymenium. In M. pumila, M. taitensis and $M$. versicolor, the granules are scattered across the hymenium, sometimes clustered (M. taitensis) or occasionally not visible at all (M. pumila).

\section{Discussion}

Based on new collections from the Taita Hills, Kenya, we describe four species: M. pumila sp. nov., $M$. stellaris sp. nov., $M$. taitensis sp. nov. and $M$. versicolor sp. nov. Three of the new species are nested in the M. prasina group, and the fourth (M. taitensis) resolves as a basal taxon to this group. The phylogenetic placement of our new species is also supported by their phenotypic characters.

We continued to investigate the use of crystalline granules as a character for species delimitation (Guzow-Krzemińska et al. 2019; Launis et al. 2019a, b). The granules were found to be highly informative for the description of $M$. stellaris, in which they appear as an intense belt-like continuum across the lower hymenium. However, they were not found to be particularly useful for the delimitations of $M$. pumila, M. taitensis and M. versicolor. In those species, the granules are either occasionally absent (M. pumila) or simply scattered across the hymenium, sometimes clustered (M. taitensis). The chemical composition of the crystalline granules remains unclear.

Half $(50 \%)$ of the indigenous forests of the Taita Hills were replaced with exotic tree plantations between 1955 and 2004 (Pellikka et al. 2009), and it is estimated that the natural forest coverage in the region has diminished by up to $90 \%$ within the last 200 years (Rodgers 1993). Therefore, it is important to understand how well epiphytic lichen diversity could survive in the exotic forest plantations. Concerning Micarea, examples of such translocations between natural and planted forests have already been observed in the Azores and Réunion (Purvis \& James 1993; Brand et al. 2014). In Tasmania, however, Micarea species were found to be sensitive to ecological change, such as logging, silvicultural treatments and fire. Interestingly, the Tasmanian examples vividly demonstrate how species in this genus are adapted to a wide range of ecological niches: almost all the species of Micarea from unlogged forest were replaced by other Micarea species that 
proliferatedin just 3-5 years after the logging (Jarman \& Kantvilas 2001a, b; Kantvilas \& Jarman 2006; Kantvilas et al. 2015).

Our results from Ngangao and Vuria show that at least some Micarea species have found favourable habitats in the Pinus patula plantations. In these locations, the species were encountered frequently, especially on dead wood. This result is not particularly surprising, since the Pinus plantations are quite similar to the environments epiphytic Micarea species inhabit elsewhere in the world, that is habitats with medium to high precipitation and substrata of low $\mathrm{pH}$ such as bark and wood of coniferous trees (e.g. Coppins 1983; Czarnota 2007). Micarea is also recognized as one of the major lichen groups on dead wood in North America and Fennoscandia (Spribille et al. 2008), which is in line with our discoveries from the Taita Hills.

Since the majority of our collections are from Pinus plantations, the question arises: are the new species in fact native or unintentionally transported together with the exotic central American tree species? Unfortunately, we cannot answer this question conclusively. However, a native origin is suggested for the following reasons: 1) Micarea stellaris and M. taitensis appear to share close relationships with two species collected from Réunion, an island in the Indian Ocean east of Madagascar; 2) three specimens of $M$. versicolor were indeed collected from indigenous forests that had low human disturbance; 3) our survey effort was limited by time and resources, which particularly impacted the exploration of the indigenous forests. In these localities, finding the specific tree species with favourable $\mathrm{pH}$ and bark structure among the rich tropical biodiversity was challenging. Hence, it is possible that we just did not find the suitable tree species and that they do exist and host the source populations for the Micarea species found in the Pinus plantations.

Based on this study, and that of Brand et al. (2014), the diversity of the genus Micarea in eastern Africa and the islands in the Indian Ocean is rich, though understudied. Broader phylogeographical investigations are needed to understand the distribution, endemism and speciation of the group in this unique geographical region.

\section{The Species}

\section{Micarea pumila Kantelinen \& Myllys sp. nov.}

\section{MycoBank No.: MB 836919}

Thallus olive green to bright green, minutely granular; apothecia numerous, cream-white or pale brownish, 0.2-0.4 mm diam., plane, convex or hemispherical, simple or tuberculate, $\mathrm{K}-$ and $\mathrm{C}-$; ascospores oblong-ellipsoid or obovoid, 0-1-septate, 7.0-10.5 $\times 2.5-3.2(-3.5) \mu \mathrm{m}$; prasinic acid.

Type: Kenya, Taita Taveta, Taita Hills, Ngangao forest, near top of the mountain, Pinus patula plantation, on wood of dead standing Pinus patula $\left(c .180 \mathrm{~cm}\right.$ tall), $3.355015^{\circ} \mathrm{S}$, $38.338873^{\circ} \mathrm{E}, 1868 \mathrm{~m}$ a.s.l., 23 November 2017, Annina Kantelinen 4630 (H-holotype; NAIisotype). GenBank Accession number: MT982140 (mtSSU).

(Fig. 2A \& B)

Thallus effuse, olive green to bright green, minutely granular, composed of goniocysts, $12-30 \mu \mathrm{m}$ diam., usually coalescing to form larger granules; photobiont micareoid, algal cells $4.5-7.5 \mu \mathrm{m}$ diam.

Apothecia numerous, cream-white or pale brownish, 0.2-0.4 mm diam., plane, convex or hemispherical, simple or sometimes tuberculate, $\mathrm{K}-$ and $\mathrm{C}-$; hypothecium hyaline; hymenium hyaline, $c$. 40-52 $\mu \mathrm{m}$ high; epihymenium hyaline; paraphyses numerous, $1.2-2.0 \mu \mathrm{m}$ wide with apices not wider or increasing up to $2.7 \mu \mathrm{m}$, mostly branched, sometimes branched 1-2 times from 
the apices resulting in a fork-like appearance; asci clavate, Micarea-type, 8 -spored, 25-35 $\times 8-10$ $\mu \mathrm{m}$; ascospores oblong-ellipsoid or obovoid, 0-1-septate, 7.0-10.5 × 2.5-3.2(-3.5) $\mu \mathrm{m}$.

Pycnidia of one type; mesopycnidia, sessile or immersed within goniocysts, whitish, $\mathrm{K}-$ and $\mathrm{C}-$, globose or barrel-shaped, up to $90 \mu \mathrm{m}$ wide; mesoconidia cylindrical or cylindrical-fusiform, $4.0-5.2 \times 1.0-1.5 \mu \mathrm{m}$.

Crystals (studied in polarized light) spread across the hymenium, often rather weakly polarizing, or not visible at all. Soluble in K (Fig. 3A).

Chemistry. Prasinic acid.

Etymology. 'Pumila' (Latin) meaning small/dwarf, referring to the small size and inconspicuous appearance of the species.

Habitat and distribution. Micarea pumila is known from a Pinus patula plantation near the top of Ngangao Mountain. The species was collected from two trunks of fallen decaying Pinus patula (Fig. 4C \& D).

Notes. Micarea pumila is characterized by a minutely granular thallus, small cream-white or pale brownish apothecia and small ascospores. It resembles species in the $M$. prasina complex, especially M. fallax Launis \& Myllys and M. prasinastra Coppins \& Kantvilas. The small whitish apothecia are also similar to $M$. micrococca and $M$. pseudomicrococca. The main morphological characters separating $M$. pumila from the other species are the smaller ascospore size and wider paraphyses, with the exception of $M$. prasinastra which has a similar ascospore size but the thallus contains gyrophoric acid. In addition, the geographical distribution of these species is not known to overlap.

In the phylogenetic analysis, $M$. pumila is nested within the $M$. prasina complex. The species forms a well-supported group with another new species from the Taita Hills, M. versicolor. The close relationship probably reflects a geographical and evolutionary isolation that these two species have encountered in the mountains. However, M. pumila and M. versicolor are morphologically quite distinct. They can be separated by the structure of the thalli (minutely granular vs warted-areolate, respectively), size and pigmentation of the apothecia (bigger and $\mathrm{K}+$ violet when pigmented in $M$. versicolor), ascospore size $(7.0-10.5 \times 2.5-3.2(-3.5) \mu \mathrm{m}$ vs $9.5-13.0$ $\times 3.2-4.0 \mu \mathrm{m}$, respectively) and secondary metabolites (prasinic acid vs methoxymicareic acid).

Additional specimen examined. Kenya: Taita Taveta: Taita Hills, Ngangao forest, west side, near top of the mountain, Pinus plantation, by a forest path, on wood of fallen decaying Pinus patula trunk, $3.366105^{\circ} \mathrm{S}, 38.341582^{\circ} \mathrm{E}, 1850 \mathrm{~m}$ a.s.1., 2017, Annina Kantelinen 4632 (H, NAI).

\section{Micarea stellaris Kantelinen \& Myllys sp nov.}

\section{MycoBank No.: MB 836920}

Thallus whitish green to bright green, warted-areolate; apothecia numerous, cream-white, usually darker at the centre, 0.3-0.5(-0.6) mm diam., adnate, convex, simple; hymenium light grey or brownish, pigment dissolving in $\mathrm{K}$; crystalline granules intense, appearing as a belt-like continuum across lower hymenium; ascospores, oblong-ellipsoid or obovoid, 0-1-septate, 10.0-14.0 × 3.8-5.0 $\mu \mathrm{m}$; methoxymicareic acid.

Type: Kenya, Taita Taveta, Taita Hills, Ngangao forest, east side, near road, by a path in the indigenous forest, on wood of decaying fallen tree trunk, $3.370467^{\circ} \mathrm{S}, 38.340808^{\circ} \mathrm{E}, 1808 \mathrm{~m}$ a.s.1., 
24 November 2017, Annina Kantelinen 4625 (H-holotype; NAI-isotype). GenBank Accession numbers:MT981448 (Mcm7), MT982139 (mtSSU).

(Fig. 2C \& D)

Thallus effuse, whitish green to bright green, warted-areolate; photobiont micareoid, algal cells 4.5$7.5 \mu \mathrm{m}$ diam.

Apothecia numerous, cream-white, usually darker at the centre, 0.3-0.5(-0.6)mm diam., adnate, convex, simple; hypothecium hyaline or slightly pigmented near hymenium; hymenium light grey or brownish, pigment $\mathrm{K}$ - and dissolving (possibly Elachista-brown pigment), 50-60 $\mu \mathrm{m}$ high; epihymenium hyaline; paraphyses numerous, mostly branched, 0.8-1.2 (-1.5) $\mu \mathrm{m}$ wide, slightly wider or not at the apices; asci clavate, Micarea-type, 8-spored, 42-50 $\times 10-13 \mu \mathrm{m}$; ascospores oblong-ellipsoid or obovoid, 0-1-septate, 10.0-14.0 ×3.8-5.0 $\mu \mathrm{m}$.

Pycnidia of one type; micropycnidia immersed in thallus, small and inconspicuous, whitish, $\mathrm{K}$ - and $\mathrm{C}-$, globose, up to $80 \mu \mathrm{m}$ wide; microconidia filiform to narrowly fusiform, straight or slightly curved, $6.5-8.0 \times 0.8-1.0 \mu \mathrm{m}$.

Crystals (studied in polarized light) intense, appearing as a belt-like continuum across lower hymenium. Soluble in K (Fig. 3B).

Chemistry. Methoxymicareic acid.

Etymology. 'Stellaris' (Latin) meaning star, referring to the intensely shining crystalline granules.

Habitat and distribution. Micarea stellaris is known from two localities on Ngangao Mountain: an indigenous forest (Fig. 4A) and a Pinus patula plantation (Fig. 4C). In both localities the new species grew on wood of dead fallen tree trunks (Pinus patula and an unidentified, likely native tree species).

Notes. Micarea stellaris is characterized by a warted-areolate thallus, light grey or brownish $\left(\mathrm{K}^{-}\right)$ pigment in the hymenium, and intensely polarizing crystals appearing as a belt-like continuum across the lower hymenium. It resembles Micarea taitensis and M. versicolor but differs in the production of hymenial pigmentation and the intense crystals. Based on our phylogenetic analysis, the three species are not particularly closely related (Fig. 1).

In the phylogenetic analysis, $M$. stellaris resolves as a sister to Micarea levicula, and is nested within the M. micrococca complex. The specimen of M. levicula in our analysis was originally collected from a natural stand of Acacia heterophylla on the island of Réunion by Brand et al. (2014). However, we also collected a specimen of M. levicula from the Taita Hills, Vuria, and it is new to Kenya. The two species resemble each other in many respects, such as the similar ecological preferences, and the shape and size of the apothecia. The main morphological features separating them are the structure of the thallus, ascospore size, pigmentation in the apothecia and secondary metabolites. Micarea levicula forms a thallus of delicately coralloid goniocysts which is distinctly different to the warted-areolate thallus of $M$. stellaris. The apothecia of M. levicula are non-pigmented throughout, the ascospores are thinner $(3.7-4.1 \mu \mathrm{m}$ vs $3.8-5.0 \mu \mathrm{m}$ wide in $M$. stellaris) and it produces gyrophoric acid instead of methoxymicareic acid.

Selected specimens examined. Kenya: Taita Taveta: Taita Hills, Ngangao forest, west side, near Ngangao Forest Camp and by a forest path, indigenous forest, on wood of decaying fallen tree trunk, $3.370565^{\circ} \mathrm{S}, 38.346693^{\circ} \mathrm{E}, 1834 \mathrm{~m}$ a.s.1., 2017, Annina Kantelinen 4633 (H); ibid., near top of the mountain, indigenous forest, by a forest path, on wood of a small fallen decaying tree trunk, $3.368355^{\circ} \mathrm{S}, 38.343012^{\circ} \mathrm{E}, 1844 \mathrm{~m}$ a.s.l., 2017, Annina Kantelinen 4634 (H, NAI). 
Micarea levicula specimen examined. Kenya: Taita Taveta: Taita Hills, Vuria, NE slope of the mountain, indigenous forest, near road to the hilltop, on wood of a decaying stump $c .1 \mathrm{~m}$ tall, in shade, together with $M$. versicolor, $3.39969444^{\circ} \mathrm{S}, 38.36472222^{\circ} \mathrm{E}, 2040 \mathrm{~m}$ a.s.1., 2017, Annina Kantelinen 4648 \& Marko Hyvärinen $(\mathrm{H})$.

\title{
Micarea taitensis Kantelinen \& Myllys sp. nov.
}

\author{
MycoBank No.: MB 836921
}

Thallus whitish green to bright green, warted-areolate or sometimes membranate; apothecia numerous, cream-white or yellowish, often with a greyish tinge because of the Sedifolia-grey pigment (K士 violet and $\mathrm{C} \pm$ violet), 0.4-0.6 mm diam., adnate, convex, simple; ascospores oblongellipsoid or obovoid, (0-)1(-2)-septate, when 1-septate often slightly constricted at the septum, $10.0-14.0 \times 4.0-4.7(-5.0) \mu \mathrm{m}$; methoxymicareic acid.

Type: Kenya, Taita Taveta, Taita Hills, Ngangao forest, Pinus plantation near top of the mountain, on bark of fallen decaying Pinus patula trunk, $3.368355^{\circ} \mathrm{S}, 38.343012^{\circ} \mathrm{E}, 1850 \mathrm{~m}$ a.s.1., 24 November 2017, Annina Kantelinen 4623 (H-holotype; NAI-isotype). GenBank Accession numbers: MT981446 (Mcm7), MT982137 (mtSSU).

(Fig. 2E \& F)

Thallus effuse, whitish green to bright green, warted-areolate or sometimes membranate, bright green especially in parts distinctly warted; photobiont micareoid, algal cells $4.5-7.5 \mu \mathrm{m}$ diam.

Apothecia numerous, cream-white or yellowish, often with a greyish tinge because of the Sedifolia-grey pigment (K士 violet and $\mathrm{C} \pm$ violet), 0.4-0.6 mm diam., adnate, convex, simple; hypothecium hyaline; hymenium hyaline, $c .45-60 \mu \mathrm{m}$ high; epihymenium hyaline; paraphyses numerous, branched or straight, $0.8-1.2 \mu \mathrm{m}$ wide, apices not widening; asci clavate, Micarea-type, 8-spored, 30-48 × 13-17 $\mu \mathrm{m}$; ascospores oblong-ellipsoid or obovoid, (0-)1(-2)-septate, when 1septate often slightly constricted at the septum, 10.0-14.0 ×4.0-4.7(-5.0) $\mu \mathrm{m}$.

Pycnidia of one type; micropycnidia immersed in thallus, small and inconspicuous, whitish, $\mathrm{K}-$ and $\mathrm{C}^{-}$, globose, up to $80 \mu \mathrm{m}$ wide; microconidia filiform to narrowly fusiform, straight or slightly curved, $6.5-8.0 \times 0.8-1.0 \mu \mathrm{m}$. (Fig. 3C).

Crystals (studied in polarized light) visible in hymenium, sometimes clustered. Soluble in K

Chemistry. Methoxymicareic acid.

Etymology. The name M. taitensis refers to the type locality, the Taita Hills.

Habitat and distribution. Micarea taitensis was found on the bark of Pinus patula from Ngangao Mountain. The type locality is a mature Pinus patula plantation near the top of the mountain, and it is so far known only from that locality (Fig. 4C).

Notes. Micarea taitensis is characterized by a warted-areolate thallus and pale cream or yellowish apothecia that sometimes produce the Sedifolia-grey pigment. Macroscopically it resembles Micarea stellaris and M. versicolor, two other new species from the Taita Hills. However, the species differ in their microscopic features. Micarea stellaris produces a light grey or brownish pigment in the hymenium, and in polarized light it exhibits intense crystalline granules that appear as a belt-like continuum across the lower hymenium. Micarea versicolor, on the other hand, develops apothecia varying in colour from cream-white to blackish, and it has slightly thinner ascospores (3.2-4.0 $\mu \mathrm{m}$ vs $4.0-4.7 \mu \mathrm{m}$ in $M$. taitensis). The phylogenetic relationship of these 
species is not particularly close, but instead $M$. taitensis resolves as a basal lineage to the $M$. prasina group (Fig. 1).

Micarea taitensis is possibly closely related to M. sublithinella, a species known from Madagascar and Réunion (Brand et al. 2014). These two species share morphological and ecological similarities. Both develop a warted thallus and grow in montane forests on acidic bark (Acacia heterophylla and Pinus patula). However, M. taitensis develops paler apothecia and thinner ascospores (4.0-4.7 $\mu \mathrm{m}$ vs 5.0-5.8 $\mu \mathrm{m}$ ), and produces methoxymicareic acid, whereas $M$. sublithinella produces protolichesterinic acid. So far, their distribution is not known to overlap.

\section{Micarea versicolor Kantelinen, Hyvärinen \& Myllys sp. nov.}

MycoBank No.: MB 836922

Thallus whitish green to bright green, warted-areolate or continuous crust, sometimes partly granular and then composed of goniocysts; apothecia numerous, cream-white to light grey to dark brownish grey or almost black (Sedifolia-grey and a purplish brown pigment), K+ intensifying purple and $\mathrm{K}+$ violet if pigmented, $0.3-0.6 \mathrm{~mm}$ diam., adnate, convex to slightly hemispherical, simple; ascospores oblong-ellipsoid or obovoid, 0-1-septate, 9.5-13.0 ×3.2-4.0(-4.5) $\mu \mathrm{m}$; methoxymicareic acid.

Type: Kenya, Taita Taveta, Taita Hills, Ngangao forest, west side, near Ngangao Forest Camp and by a forest path, indigenous forest, on wood of decaying fallen tree trunk, $3.370565^{\circ} \mathrm{S}$, $38.346693^{\circ} \mathrm{E}, 1834 \mathrm{~m}$ a.s.l., 24 November 2017, Annina Kantelinen 4626 (H-holotype; NAIisotype). GenBank Accession numbers: MT981602, MT981603, MT981604 (ITS); MT982141, MT982142, MT982143, MT982144 (mtSSU).

(Fig. 2G \& H)

Thallus effuse, whitish green to bright green, quite thin, warted-areolate or continuous crust, sometimes partly granular and then composed of goniocysts of $18-40 \mu \mathrm{m}$ diam; photobiont micareoid, algal cells 4.5-7.5 $\mu \mathrm{m}$ diam.

Apothecia numerous, cream-white or light grey to dark brownish grey to almost black (Sedifolia-grey and a purplish brown pigment), $\mathrm{K}+$ intensifying purple and $\mathrm{K}+$ violet when pigmented, 0.3-0.6 mm diam., adnate, convex to slightly hemispherical, simple; hypothecium hyaline; hymenium hyaline or purplish brown, $\mathrm{K}+$ purple intensifying when pigmented, $c .42-50$ $\mu \mathrm{m}$ high. Epihymenium hyaline to purplish brown or greenish grey, $\mathrm{K}+$ violet; paraphyses numerous, branched, 1.2-2.0 $\mu \mathrm{m}$ wide, slightly wider or not at the apices; asci clavate, Micareatype, 8-spored, 32-45 × 10-17 $\mu \mathrm{m}$; ascospores oblong-ellipsoid or obovoid, 0-1-septate, 9.5-13.0 $\times 3.2-4.0(-4.5) \mu \mathrm{m}$.

Pycnidia of one type; micropycnidia numerous, sessile or immersed in thallus, cream-white, $\mathrm{K}^{-}$and $\mathrm{C}^{-}$, globose or barrel-like, sometimes with gaping ostiole, up to $100 \mu \mathrm{m}$ wide; microconidia filiform to narrowly fusiform, straight or slightly curved, 7.0-9.0 $\times 0.8-1.0 \mu \mathrm{m}$.

Crystals (studied in polarized light) visible in hymenium and upper part of hypothecium. Soluble in K (Fig. 3D).

Chemistry. Methoxymicareic acid.

Etymology. The epithet versicolor refers to the coloration of the apothecia that vary considerably from cream-white to pale grey and to almost black.

Habitat and distribution. Micarea versicolor is known from four localities: two are in the indigenous forest on Ngangao Mountain, the third in a Pinus patula plantation near the top of 
Ngangao and the fourth in a small patch of indigenous forest on Vuria Mountain (Fig. 4B). In all localities the species grew on dead wood of fallen or standing tree species (Pinus patula and unidentified native trees).

Notes. Micarea versicolor is characterized by the warted-areolate, sometimes partly granular thallus and apothecia that vary in colour from cream-white to light grey to blackish. This considerable variation in the coloration of the apothecia is probably caused by a mixture of pigments that can occur independently of one another: 1) Sedifolia-grey pigment in the epihymenium (K+ violet, $\mathrm{C}+$ violet), which is a common pigment in the M. prasina group and produced especially in response to sunlight; 2) a purplish brown pigment in the hymenium (K+ intensifying purple) that may either be the same as that known from the hypothecium of M. melaena, or an unknown pigment somewhat similar to that found in the hymenium of Bacidia schweinitzii s. str. (a species also known for having high variation in the coloration of its apothecia; see Ekman (1996) and Lendemer et al. (2016)). This mixture of pigments causes the apothecia of $M$. versicolor to appear as cream-white (no pigments), greyish (Sedifolia-grey pigment only), or dark brownish grey to blackish (purplish brown pigment + Sedifolia-grey pigment).

Macroscopically $M$. versicolor resembles two other new species from the Taita Hills, $M$. stellaris and $M$. taitensis. These species can be separated by microscopic features that include the pigmentation of the apothecia and hymenium, crystalline granules in polarized light and ascospore width (see more details under $M$. taitensis).

Based on our phylogenetic analysis, $M$. versicolor is not closely related to M. stellaris or $M$. taitensis. Instead it is sister to $M$. pumila and nested within the M. prasina complex, although with low support in the latter. Morphologically the sister species M. versicolor and M. pumila are quite distinct: $M$. pumila develops a minutely granular thallus composed of goniocysts, has smaller unpigmented apothecia ( $\mathrm{K}-$ and $\mathrm{C}-$ ) and smaller ascospores $(7.0-10.5 \times 2.5-3.2(-3.5) \mu \mathrm{m}$ vs $9.5-$ $13.0 \times 3.2-4.0(-4.5) \mu \mathrm{m})$. They also produce different secondary metabolites: $M$. versicolor produces methoxymicareic acid, whereas $M$. pumila produces prasinic acid.

Selected specimens examined. Kenya: Taita Taveta: Taita Hills, Ngangao forest, west side, near top of the mountain, Pinus plantation, by a forest path, on wood of fallen decaying Pinus patula trunk, $3.366105^{\circ} \mathrm{S}, 38.341582^{\circ} \mathrm{E}, 1850 \mathrm{~m}$ a.s.1., 2017, Annina Kantelinen 4624 (H, NAI); ibid., indigenous forest, by a forest path, on wood of a small fallen decaying tree truck, $3.368355^{\circ} \mathrm{S}, 38.343012^{\circ} \mathrm{E}$, 1844 m a.s.1., 2017, Annina Kantelinen 4627 (H, NAI); ibid., Vuria, NE slope of the mountain, indigenous forest, near road to the hilltop, on wood of a decaying stump $c .1 \mathrm{~m}$ tall, in shade, 3.39969444 ${ }^{\circ}$ S, $38.36472222^{\circ}$ E, 2040 m a.s.l., 2017, Annina Kantelinen 4647 \& Marko Hyvärinen (H, NAI).

Acknowledgements. Financial support for this study was provided by the Societas pro Fauna et Flora Fennica, the University of Helsinki LUOVA travel grants for doctoral candidates (personal grants for AK), and the Academy of Finland (Grant 323711). We thank the two anonymous reviewers for improving the manuscript. We would also like to acknowledge the organizers and participants of the expedition to the Taita Hills in 2017, namely Prof. Leif Schulman, head gardener Pertti Pehkonen and doctoral candidate Anton Savchenko. We also thank the Taita Research Station (University of Helsinki) for providing access to facilities and logistics during the stay. The staff and local people are warmly thanked for their helpfulness and hospitality. 
Author ORCIDs. Annina Kantelinen, 0000-0001-8664-7662; Leena Myllys, 0000-0002-95669473.

\section{References}

Alstrup V and Aptroot A (2005) Pyrenocarpous lichens from Tanzania and Kenya. Cryptogamie, Mycologie 26, 265-271.

Alstrup V and Christensen SN (2006) New records of lichens with cyanobacteria from Tanzania and Kenya. Cryptogamie, Mycologie 27, 57-68.

Andersen HL and Ekman S (2005) Disintegration of the Micareaceae (lichenized Ascomycota): a molecular phylogeny based on mitochondrial rDNA sequences. Mycological Research 109, 21-30.

Bjelland T, Bendiksby M and Frisch A (2017) Geographically disjunct phylogenetic lineages in Leptogium hibernicum reveal Leptogium krogiae sp. nov. from East Africa. Lichenologist 49, 239-251.

Brand AM, van den Boom PPG and Sérusiaux E (2014) Unveiling a surprising diversity in the lichen genus Micarea (Pilocarpaceae) in Réunion (Mascarenes archipelago, Indian Ocean). Lichenologist 46, 413-439.

Burgess ND, Butynski TM, Cordeiro NJ, Doggart NH, Fjeldså J, Howell KM, Kilahama FB, Loader SP, Lovett JC and Mbilinyi B(2006) The biological importance of the Eastern Arc Mountains of Tanzania and Kenya. Biological Conservation 134, 209-231.

Cengia Sambo M (1938) Licheni del Kenia e del Tanganica raccolti dai Rev. Padri della Consolata. Nouvo Giornale Botanico Italiano 45, 364-387.

Coppins BJ (1983) A taxonomic study of the lichen genus Micarea in Europe. Bulletin of the British Museum (Natural History), Botany Series 11, 17-214.

Coppins BJ (1999) Two new species of Micarea from South Africa. Lichenologist 31, 559-565.

Culberson CF and Kristinsson HD (1970) A standardized method for the identification of lichen products. Journal of Chromatography A 46, 85-93.

Czarnota P (2007) The lichen genus Micarea (Lecanorales, Ascomycota) in Poland. Polish Botanical Studies 23, 1-190.

Czarnota P and Guzow-Krzemińska B (2010) A phylogenetic study of the Micarea prasina group shows that Micarea micrococca includes three distinct lineages. Lichenologist 42, 721.

Edgar RC (2004) MUSCLE: multiple sequence alignment with high accuracy and high throughput. Nucleic Acids Research 32, 1792-1797.

Ekman S (1996) The corticolous and lignicolous species of Bacidia and Bacidina in North America. Opera Botanica 127, 1-148.

Ekman S and Svensson M (2014) Brianaria (Psoraceae), a new genus to accommodate the Micarea sylvicola group. Lichenologist 46, 285-294.

Ekman S, Andersen H and Wedin M (2008) The limitations of ancestral state reconstruction and the evolution of the ascus in the Lecanorales (lichenized Ascomycota). Systematic Biology 57, 141-156.

Farkas E (1987) Foliicolous lichens of the Usambara Mountains, Tanzania I. Lichenologist 19, 4359.

Farkas E and Flakus A (2015) Rare or overlooked? Two species of Lyromma (Lyrommataceae, lichenized Ascomycota) are new for Africa. Herzogia 28, 204-211.

Farkas E and Vězda A (1993) Five new foliicolous lichen species. Folia Geobotanica et Phytotaxonomica 28, 321-330.

Felsenstein J (1985) Phylogenies and the comparative method. American Naturalist 125, 1-15. 
Feuerer T (2011) Checklist of lichens and lichenicolous fungi of Kenya (preliminary version 1 March 2008). [WWW resource] URL http://www.biologie.unihamburg.de/checklists/africa/kenya_l.htm. [Accessed 9 February 2012].

Frisch A (1999) Afroalpine macrolichens of Mount Kenya (Kenya). Bayreuther Forum Ökologie 64, 65-102.

Frisch A and Hertel H (1998) Flora of macrolichens in the alpine and subalpine zones of Mount Kenya (Kenya) [Die Flora der Blatt- und Strauchflechten in der alpinen und subalpinen Stufe des Mount Kenya (Kenia)]. Sauteria 9, 363-370.

Goloboff P, Farris J and Nixon K (2008) TNT, a free program for phylogenetic analysis. Cladistics 24, 774-786.

Guzow-Krzemińska B, Czarnota P, Lubek A and Kukwa M (2016) Micarea soralifera sp. nov., a new sorediate species in the M. prasina group. Lichenologist 48, 161-169.

Guzow-Krzemińska B, Sérusiaux E, van den Boom PPG, Brand AM, Launis A, Lubek A and Kukwa M (2019) Understanding the evolution of phenotypical characters in the Micarea prasina group (Pilocarpaceae) and descriptions of six new species within the group. MycoKeys 57, 1-30.

Hafellner J (1984) Studien in Richtung einer natürlicheren Gliederung der Sammelfamilien Lecanoraceae und Lecideaceae. Beiheft zur Nova Hedwigia 79, 241-371.

Harris RC (2009) Four novel lichen taxa in the lichen biota of eastern North America. Opuscula Philolichenum 6, 149-156.

International Mycological Association (2019) MycoBank Database. [WWW resource] URL www.mycobank.org. [Accessed May 2019].

Jarman SJ and Kantvilas G (2001a) Bryophytes and lichens at the Warra LTER Site. I. An inventory of species in Eucalyptus obliqua wet sclerophyll forest. Tasforests 13, 193-216.

Jarman SJ and Kantvilas G (2001b) Bryophytes and lichens at the Warra LTER Site. II. Understorey habitats in Eucalyptus obliqua wet sclerophyll forest. Tasforests 13, 217-243.

Jørgensen PM (1994) Leptogium palustre, a new lichen from East Africa. Lichenologist 26, 213215.

Kalb K and Vězda A (1994) Neue Arten der Flechtengattung Gyalideopsis Vězda (Gomphillaceae). Nova Hedwigia 58, 511-528.

Kantvilas G and Coppins BJ (2019) Studies on Micarea in Australasia II. A synopsis of the genus in Tasmania, with the description of ten new species. Lichenologist 51, 431-481.

Kantvilas G and Jarman SJ (2006) Recovery of lichens after logging: preliminary results from Tasmania's wet forests. Lichenologist 38, 383-394.

Kantvilas G, Jarman SJ and Minchin PR (2015) Early impacts of disturbance on lichens, mosses and liverworts in Tasmania's wet eucalypt production forests. Australian Forestry 78, 92107.

Kauff F and Lutzoni F (2002) Phylogeny of the Gyalectales and Ostropales (Ascomycota, Fungi): among and within order relationships based on nuclear ribosomal RNA small and large subunits. Molecular Phylogenetics and Evolution 25, 138-156.

Kirika P, Mugambi G, Lücking R and Lumbsch HT (2012) New records of lichen-forming fungi from Kenya. Journal of East African Natural History 101, 73-98.

Klement O (1962) Zur Flechten-Vegetation von Tanganjika. Stuttgarter Beiträge zur Naturkunde 85, $1-8$.

Konoreva L, Chesnokov S, Kuznetsova E and Stepanchikova I (2019) Remarkable records of Micarea from the Russian Far East and significant extension of Micarea laeta and $M$. microareolata range. Botanica 25, 186-201.

Lange CD (2006) The endemic land snail Gulella taitensis of the Taita Hills forests, Kenya: on the brink of extinction. Oryx 40, 362-364. 
Launis A and Myllys L (2019) Micarea fennica, a new lignicolous lichen species from Finland. Phytotaxa 409, 179-188.

Launis A, Pykälä J, van den Boom P, Sérusiaux E and Myllys L (2019a) Four new epiphytic species in the Micarea prasina group from Europe. Lichenologist 51, 7-25.

Launis A, Malicek J, Svensson M, Tsurykau A, Sérusiaux E and Myllys L (2019b) Sharpening species boundaries in the Micarea prasina group, with a new circumscription of the type species M. prasina. Mycologia 111, 574-592.

Leavitt SD, Johnson L, Goward T and St. Clair L (2011) Species delimitation in taxonomically difficult lichen-forming fungi: an example from morphologically and chemically diverse Xanthoparmelia (Parmeliaceae) in North America. Molecular Phylogenetics and Evolution 60, 317-332.

Lendemer JC, Harris RC and Ladd D (2016) The faces of Bacidia schweinitzii: molecular and morphological data reveal three new species including a widespread sorediate morph. Bryologist 119, 143-171.

Lücking R and Kalb K (2002) New species and further additions to the foliicolous lichen flora of Kenya (East Africa), including the first lichenicolous Aulaxina (Ostropales:

Gomphillaceae). Botanical Journal of the Linnean Society 139, 171-180.

Maas Geesteranus RA (1955) Some lichenological observations in Kenya. Webbia 11, 519-523.

Malonza PK, Lötters S and Measey GJ (2010) The montane forest associated amphibian species of the Taita Hills, Kenya. Journal of East African Natural History 99, 47-63.

Marbach B (2000) Corticole und lignicole Arten der Flechtengattung Buellia sensu lato in den Subtropen und Tropen. Bibliotheca Lichenologica 74, 1-384.

Meyer B and Printzen C (2000) Proposal for a standardized nomenclature and characterization of insoluble lichen pigments. Lichenologist 32, 571-583.

Myllys L, Lohtander K, Källersjö M and Tehler A (1999) Sequence insertion and ITS data provide congruent information in Roccella canariensis and $R$. tuberculata (Arthoniales, Euascomycetes) phylogeny. Molecular Phylogenetics and Evolution 12, 295-309.

Myllys L, Velmala S, Holien H, Halonen P, Wang LS and Goward T (2011) Phylogeny of the genus Bryoria. Lichenologist 43, 617-638.

Orange A, James PW and White FJ (2010) Microchemical Methods for the Identification of Lichens. London: British Lichen Society.

Pellikka PK, Lotjonen M, Siljander M and Lens L (2009) Airborne remote sensing of spatiotemporal change (1955-2004) in indigenous and exotic forest cover in the Taita Hills, Kenya. International Journal of Applied Earth Observation and Geoinformation 11, 221232.

Purvis OW and James PW (1993) Studies on the lichens of the Azores. Part 1: Caldeira Faial. Arquipélago, Life and Marine Sciences 11A, 1-15.

Rikkinen J (2010) Cyanolichens of the Taita Hills and Mt. Kasigau. In Johansson T, Pellikka P and Sorvali J (eds), Safari Njema - an Interdisciplinary Field Expedition to South-East Kenya. Helsinki: Department of Geography, University of Helsinki, pp. 64-68.

Rodgers W (1993) The conservation of the forest resources of eastern Africa: past influences, present practices and future needs. In Lovett $\mathbf{J}$ and Wasser $\mathrm{S}$ (eds), Biogeography and Ecology of the Rain Forests of Eastern Africa. Cambridge: Cambridge University Press, pp. 283-332.

Rogers PC, O'Connell B, Mwang'ombe J, Madoffe S and Hertel G (2008) Forest health in the Ngangao Forest, Taita Hills, Kenya: a five year assessment of change. Journal of East African Natural History 97, 3-17.

Rogo L and Oguge N (2000) The Taita Hills forest remnants: a disappearing world heritage. AMBIO: A Journal of the Human Environment 29, 522-523. 
Santesson R (1952) Foliicolous lichens I. A revision of the taxonomy of the obligately foliicolous, lichenized fungi. Symbolae Botanicae Upsaliensis 12, 1-590.

Schmitt I, Crespo A, Divakar PK, Fankhauser JD, Herman-Sackett E, Kalb K, Nelsen MP, Nelson NA, Rivas-Plata E and Shimp AD (2009) New primers for promising single-copy genes in fungal phylogenetics and systematics. Persoonia 23, 35-40.

Sérusiaux E, Brand AM, Motiejūnaitè J, Orange A and Coppins BJ (2010) Lecidea doliiformis belongs to Micarea, Catillaria alba to Biatora and Biatora lignimollis occurs in Western Europe. Bryologist 113, 333-344.

Spribille T, Thor G, Bunnell FL, Goward T and Björk CR (2008) Lichens on dead wood: species-substrate relationships in the epiphytic lichen floras of the Pacific Northwest and Fennoscandia. Ecography 31, 741-750.

Stamatakis A (2014) RAxML version 8: a tool for phylogenetic analysis and post-analysis of large phylogenies. Bioinformatics 30, 1312-1313.

Suija A, Kaasalainen U, Kirika P and Rikkinen J (2018) Taitaia, a novel lichenicolous fungus in tropical montane forests in Kenya (East Africa). Lichenologist 50, 173-184.

Swinscow TDV and Krog H (1988) Macrolichens of East Africa. London: British Museum (Natural History).

van den Boom PPG, Brand AM, Coppins BJ and Sérusiaux E (2017) Two new species in the Micarea prasina group from Western Europe. Lichenologist 49, 13-25.

White TJ, Bruns T, Lee S and Taylor JW (1990) Amplification and direct sequencing of fungal ribosomal RNA genes for phylogenetics. In Innis MA, Gelfand DH, Sninsky JJ and White TJ (eds), PCR Protocols: A Guide to Methods and Applications. New York: Academic Press, pp. 315-322.

Wilder C, Brooks T and Lens L (1998) Vegetation structure and composition of the Taita Hills forests. Journal of East African Natural History 87, 181-187.

Yeshitela K (2008) Effects of anthropogenic disturbance on the diversity of foliicolous lichens of East Africa: Goder (Ethiopia), Budongo (Uganda) and Kakamega (Kenya). Ph.D. thesis, University of Koblenz-Landau.

Yeshitela K, Fischer E, Killmann D and Sérusiaux E (2009) Two new foliicolous species of Enterographa (Roccellaceae) from Kenya. Lichenologist 41, 17-23.

Zahlbruckner A (1926) Afrikanische Flechten (Lichenes). Engler's Botanische Jahrbücher 60, 468-552.

Zoller S, Scheidegger C and Sperisen C (1999) PCR primers for the amplification of mitochondrial small subunit ribosomal DNA of lichen-forming ascomycetes. Lichenologist 31, 511-516. 
Table 1. List of Micarea specimens used in the phylogenetic analyses with locality, voucher information and GenBank Accession numbers. New species and new sequences generated for the current study are marked in bold.

\begin{tabular}{|c|c|c|c|c|c|}
\hline Taxon & Locality & $\begin{array}{l}\text { Voucher } \\
\text { information, } \\
\text { sequence ID }\end{array}$ & ITS & mtSSU & Mcm7 \\
\hline M. adnata & Japan & Andersen 48 (BG) & AY756468 & AY567751 & - \\
\hline $\begin{array}{l}\text { M. } \\
\text { aeruginoprasina }\end{array}$ & $\begin{array}{l}\text { Portugal, } \\
\text { Azores }\end{array}$ & $\begin{array}{l}\text { van den Boom } \\
51445 \text { (LG), } 3973\end{array}$ & - & MK562024 & MN105888 \\
\hline M. azorica & $\begin{array}{l}\text { Portugal, } \\
\text { Azores }\end{array}$ & $\begin{array}{l}\text { van den Boom } \\
51468 \text { (LG), } 3977\end{array}$ & - & MK562026 & MN105891 \\
\hline M. byssacea & Finland & $\begin{array}{l}\text { Launis } 289103(\mathrm{H}) \text {, } \\
\text { A98 }\end{array}$ & MG521562 & MG707768 & MG692527 \\
\hline M. czarnotae & Finland & $\begin{array}{l}\text { Launis } 1010133(\mathrm{H}) \text {, } \\
\text { A455 }\end{array}$ & MG521557 & MG707760 & MG692517 \\
\hline M. elachista & Finland & $\begin{array}{l}\text { Launis } 67113(\mathrm{H}) \\
\text { A340 }\end{array}$ & MG521548 & MG707745 & - \\
\hline M. endocyanea & USA, Maine & $\begin{array}{l}\text { Kantelinen } 4449(\mathrm{H}), \\
\text { A325 }\end{array}$ & MT981601 & MT982135 & MT981445 \\
\hline M. eximia & Finland & $\begin{array}{l}\text { Kantelinen } 3785(\mathrm{H}), \\
\text { A785 }\end{array}$ & MT981600 & MT982134 & MT981444 \\
\hline M. eximia & Finland & $\begin{array}{l}\text { Kantelinen } 3734(\mathrm{H}) \text {, } \\
\text { A789 }\end{array}$ & MT981599 & MT982133 & MT981443 \\
\hline M. fallax & Finland & $\begin{array}{l}\text { Launis } 59132(\mathrm{H}) \\
\text { A559 }\end{array}$ & MK454942 & MK454759 & MK456617 \\
\hline M. fennica & Finland & $\begin{array}{l}\text { Launis } 3220(\mathrm{H}) \\
\text { A790 }\end{array}$ & MK517712 & MK517716 & MK520931 \\
\hline M. fennica & Finland & Launis $68(\mathrm{H}), \mathrm{A} 117$ & MK517711 & MK517715 & MK520930 \\
\hline M. flavoleprosa & France & $\begin{array}{l}\text { Sérusiaux s. n. (LG), } \\
3841\end{array}$ & - & MK454754 & MK456613 \\
\hline M. flavoleprosa & Czech Republic & $\begin{array}{l}\text { Maliček } 5098(\mathrm{H}), \\
\text { A616 }\end{array}$ & - & MK454756 & MK456615 \\
\hline M. globulosella & Finland & $\begin{array}{l}\text { Launis } 67112(\mathrm{H}), \\
\text { A240 }\end{array}$ & MG521546 & MG707743 & MG692507 \\
\hline M. hedlundii & Finland & $\begin{array}{l}\text { Launis } 67119(\mathrm{H}) \\
\text { A254 }\end{array}$ & MG521551 & MG707749 & MG692512 \\
\hline M. herbarum & Netherlands & $\begin{array}{l}P \& \text { \& van den Boom } \\
52575 \text { (hb. van den } \\
\text { Boom), LG DNA } 4236\end{array}$ & - & KX459349 & MG692513 \\
\hline M. incrassata & Finland & $\begin{array}{l}\text { Kantelinen } 90(\mathrm{H}), \\
\text { A90 }\end{array}$ & MT981598 & MT982132 & MT981442 \\
\hline M. isidioprasina & France & $\begin{array}{l}\text { Sérusiaux s. n. (LG), } \\
3437\end{array}$ & MN095788 & KX459362 & MN105894 \\
\hline M. isidioprasina & Poland & $\begin{array}{l}\text { Kukwa 17367a \& } \\
\text { tubek (UGDA) }\end{array}$ & MN095789 & MK562016 & MN105897 \\
\hline
\end{tabular}




\begin{tabular}{|c|c|c|c|c|c|}
\hline M. laeta & Finland & $\begin{array}{l}\text { Launis } 59153(\mathrm{H}) \\
\text { A825 }\end{array}$ & MG521565 & MG707771 & MG692530 \\
\hline M. levicula & $\begin{array}{l}\text { France, } \\
\text { Réunion }\end{array}$ & $\begin{array}{l}\text { Sérusiaux s. n. (LG), } \\
3532\end{array}$ & - & MK562019 & MN105900 \\
\hline M. melanobola & Finland & $\begin{array}{l}\text { Launis } 27123(\mathrm{H}) \\
\text { A437 }\end{array}$ & MK454946 & MK454770 & MK456625 \\
\hline M. melanobola & Finland & $\begin{array}{l}\text { Launis } 11014(\mathrm{H}) \text {, } \\
\text { A424 }\end{array}$ & MK454950 & MK454774 & MK456630 \\
\hline M. meridionalis & Portugal & $\begin{array}{l}\text { van den Boom s. n. } \\
\text { (LG), } 4279\end{array}$ & - & KX459353 & MN105901 \\
\hline M. microareolata & Sweden & $\begin{array}{l}\text { Launis } 148131(\mathrm{H}), \\
\text { A393 }\end{array}$ & MG521558 & MG707762 & MG692518 \\
\hline M. micrococca & Finland & $\begin{array}{l}\text { Launis } 299101(\mathrm{H}) \text {, } \\
\text { A100 }\end{array}$ & MG521552 & MG707753 & MG692514 \\
\hline $\begin{array}{l}\text { M. } \\
\text { microsorediata }\end{array}$ & Poland & $\begin{array}{l}\text { Kukwa } 17053 \\
\text { (UGDA) }\end{array}$ & MN095791 & MK562012 & MN105906 \\
\hline M. misella & Finland & $\begin{array}{l}\text { Launis } 108111(\mathrm{H}), \\
\text { A264 }\end{array}$ & MG521545 & MG707742 & MG692506 \\
\hline M. neostipitata & $\begin{array}{l}\text { USA, North } \\
\text { Carolina }\end{array}$ & $\begin{array}{l}\text { Lendemer } 29572(\mathrm{H}) \text {, } \\
\text { A347 }\end{array}$ & - & MT982136 & - \\
\hline M. nowakii & Romania & $\begin{array}{l}\text { Sérusiaux s. n. (LG), } \\
4380\end{array}$ & - & KX459359 & MN105908 \\
\hline M. pauli & Poland & $\begin{array}{l}\text { Kukwa } 17544 \text { \& } \\
\text { Łubek (UGDA) }\end{array}$ & MN095795 & MK562010 & MN105913 \\
\hline M. peliocarpa & USA, Maine & $\begin{array}{l}\text { Launis } 66123(\mathrm{H}) \\
\text { A324 }\end{array}$ & MG521544 & MG707741 & MG692505 \\
\hline M. prasina s. str. & Finland & $\begin{array}{l}\text { Launis } 265101(\mathrm{H}), \\
\text { A92 }\end{array}$ & MG521549 & MG707747 & MG692510 \\
\hline $\begin{array}{l}\text { M. } \\
\text { pseudomicrococc } \\
a\end{array}$ & Scotland & $\begin{array}{l}\text { Launis } 171141(\mathrm{H}) \text {, } \\
\text { A645 }\end{array}$ & MG521556 & MG707758 & MG692516 \\
\hline M. pumila & Kenya & $\begin{array}{l}\text { Kantelinen } 4630(\mathrm{H}, \\
\mathrm{NAI}), \mathrm{A} 836\end{array}$ & - & MT982140 & - \\
\hline M. pusilla & Finland & $\begin{array}{l}\text { Launis } 1010137(\mathrm{H}) \text {, } \\
\text { A460 }\end{array}$ & MK454941 & MK454752 & MK456611 \\
\hline M. pusilla & Finland & $\begin{array}{l}\text { Launis } 101035(\mathrm{H}) \\
\text { A464 }\end{array}$ & - & MK454753 & MK456612 \\
\hline M. soralifera & Poland & $\begin{array}{l}\text { Kukwa } 13001 \text { \& } \\
\text { Łubek (UGDA) }\end{array}$ & KT119887 & KT119886 & MN105917 \\
\hline M. stellaris & Kenya & $\begin{array}{l}\text { Kantelinen } 4625(\mathrm{H}, \\
\mathrm{NAI}), \mathrm{A} 831\end{array}$ & - & MT982139 & MT981448 \\
\hline $\begin{array}{l}\text { M. } \\
\text { subviridescens }\end{array}$ & Scotland & Czarnota 3599 (GPN) & - & EF453666 & - \\
\hline M. taitensis & Kenya & $\begin{array}{l}\text { Kantelinen } 4623(\mathrm{H}, \\
\mathrm{NAI}), \mathrm{A} 829\end{array}$ & - & MT982137 & MT981446 \\
\hline
\end{tabular}




\begin{tabular}{|c|c|c|c|c|c|}
\hline M. tomentosa & Finland & $\begin{array}{l}\text { Kantelinen } 2592(\mathrm{H}) \text {, } \\
\text { A414 }\end{array}$ & - & MT982138 & MT981447 \\
\hline M. versicolor & Kenya & $\begin{array}{l}\text { Kantelinen } 4624(\mathrm{H}, \\
\text { NAI), A830 }\end{array}$ & MT981604 & MT982143 & - \\
\hline M. versicolor & Kenya & $\begin{array}{l}\text { Kantelinen } 4626(\mathrm{H}, \\
\mathrm{NAI}), \mathrm{A} 832\end{array}$ & - & MT982144 & - \\
\hline M. versicolor & Kenya & $\begin{array}{l}\text { Kantelinen } 4627(\mathrm{H}, \\
\mathrm{NAI}), \text { A833 }\end{array}$ & MT981603 & MT982142 & - \\
\hline M. versicolor & Kenya & $\begin{array}{l}\text { Kantelinen } 4647(\mathrm{H}, \\
\mathrm{NAI}), \mathrm{A} 834\end{array}$ & MT981602 & MT982141 & - \\
\hline M. viridileprosa & Poland & Czarnota 3436 (GPN) & - & EF453671 & - \\
\hline M. viridileprosa & Netherlands & $\begin{array}{l}P . \& \text { B. van den } \\
\text { Boom, } 50066 \text { (hb. } \\
\text { van den Boom), LG } \\
\text { DNA } 3493\end{array}$ & - & KX459366 & MN105918 \\
\hline M. xanthonica & USA & Tønsberg 25674 (BG) & - & AY756454 & - \\
\hline $\begin{array}{l}\text { Micarea sp. (as } \\
\text { M. eximia in } \\
\text { GenBank) }\end{array}$ & not available & $\begin{array}{l}\text { Hermansson 8866b } \\
\text { (UPS) }\end{array}$ & AY756476 & AY756447 & - \\
\hline $\begin{array}{l}\text { Micarea sp. } \\
\text { 'lineage } A^{\prime}\end{array}$ & Scotland & $\begin{array}{l}\text { Launis } 171142(\mathrm{H}) \text {, } \\
\text { A648 }\end{array}$ & MG521571 & MG707782 & MG692542 \\
\hline
\end{tabular}


Table 2. A species synopsis representing the main distinguishing morphological characters for the new Micarea species and for their closest relatives or morphologically similar species.

\begin{tabular}{|c|c|c|c|c|c|c|}
\hline Species & $\begin{array}{l}\text { Thallus } \\
\text { colour }\end{array}$ & $\begin{array}{l}\text { Thallus } \\
\text { structure }\end{array}$ & $\begin{array}{c}\text { Apothecial } \\
\text { pigmentation }\end{array}$ & $\begin{array}{l}\text { Ascospore } \\
\text { size }(\mu \mathrm{m})\end{array}$ & $\begin{array}{l}\text { Crystalline } \\
\text { granules }\end{array}$ & $\begin{array}{l}\text { Secondary } \\
\text { chemistry }\end{array}$ \\
\hline M. fallax & $\begin{array}{l}\text { vivid } \\
\text { green or } \\
\text { pale to } \\
\text { dark } \\
\text { olive } \\
\text { green }\end{array}$ & $\begin{array}{l}\text { granular, } \\
\text { goniocysts } \\
\text { usually } \\
\text { aggregated } \\
\text { or form } \\
\pm \text { thick } \\
\text { almost } \\
\text { continuous } \\
\text { and cracked } \\
\text { thallus, if } \\
\text { less } \\
\text { developed } \\
\text { warted or } \\
\text { partly } \\
\text { membranous } \\
\text { and } \pm \text { shiny }\end{array}$ & $\begin{array}{c}\text { cream-white, } \\
\text { pale } \\
\text { brownish, } \\
\text { honey brown } \\
\text { to brown, } \\
\text { sometimes } \\
\text { with greyish } \\
\text { tinge, } \mathrm{K} \pm \\
\text { violet, } \mathrm{C} \pm \\
\text { violet }\end{array}$ & $\begin{array}{c}8-11 \times(3-) \\
3.2-4.0\end{array}$ & $\begin{array}{c}\text { across } \\
\text { hymenium }\end{array}$ & micareic acid \\
\hline M. levicula & $\begin{array}{l}\text { vivid } \\
\text { green }\end{array}$ & $\begin{array}{l}\text { goniocysts } \\
\text { delicately } \\
\text { coralloid } \\
\end{array}$ & $\begin{array}{l}\text { cream-white, } \\
\mathrm{K}-, \mathrm{C}-\end{array}$ & $\begin{array}{l}10.3-10.8 \\
\times 3.7-4.1\end{array}$ & not studied & gyrophoric acid \\
\hline $\begin{array}{c}M . \\
\text { micrococca }\end{array}$ & $\begin{array}{l}\text { bright } \\
\text { green to } \\
\text { pale } \\
\text { olive } \\
\text { green }\end{array}$ & $\begin{array}{c}\text { minutely } \\
\text { granular, } \\
\text { goniocysts } \\
\text { usually } \\
\text { aggregated }\end{array}$ & $\begin{array}{c}\text { cream-white, } \\
\text { K-, C- }\end{array}$ & $\begin{array}{c}10-12(- \\
16) \times 3-4.5\end{array}$ & $\begin{array}{c}\text { across } \\
\text { hymenium }\end{array}$ & $\begin{array}{c}\text { methoxymicareic } \\
\text { acid }\end{array}$ \\
\hline $\begin{array}{l}\text { M. pumila } \\
\text { sp. nov. }\end{array}$ & $\begin{array}{l}\text { olive } \\
\text { green to } \\
\text { bright } \\
\text { green }\end{array}$ & $\begin{array}{l}\text { minutely } \\
\text { granular }\end{array}$ & $\begin{array}{c}\text { cream-white } \\
\text { or pale } \\
\text { brownish, K-, } \\
\text { C- }\end{array}$ & $\begin{array}{c}7.0-10.5 \times \\
2.5-3.2(- \\
3.5)\end{array}$ & $\begin{array}{c}\text { across } \\
\text { hymenium, } \\
\text { often weak } \\
\text { or not visible }\end{array}$ & prasinic acid \\
\hline $\begin{array}{l}\text { M. stellaris } \\
\text { sp. nov. }\end{array}$ & $\begin{array}{l}\text { whitish } \\
\text { green to } \\
\text { bright } \\
\text { green }\end{array}$ & $\begin{array}{l}\text { warted- } \\
\text { areolate }\end{array}$ & $\begin{array}{l}\text { cream-white, } \\
\text { usually } \\
\text { darker at the } \\
\text { center, } \\
\text { hymenium } \\
\text { with light } \\
\text { grey or } \\
\text { brownish } \\
\text { pigment } \\
\text { dissolving in } \\
\text { K } \\
\end{array}$ & $\begin{array}{c}10.0-14.0 \\
\times 3.8-5.0\end{array}$ & $\begin{array}{l}\text { intense, } \\
\text { appearing as } \\
\text { a belt-like } \\
\text { continuum } \\
\text { across lower } \\
\text { hymenium }\end{array}$ & $\begin{array}{c}\text { methoxymicareic } \\
\text { acid }\end{array}$ \\
\hline $\begin{array}{c}\text { M. } \\
\text { sublithinella }\end{array}$ & green & $\begin{array}{l}\text { continuous } \\
\text { or areolate }\end{array}$ & $\begin{array}{c}\text { light } \\
\text { brownish, } \\
\text { dull } \\
\end{array}$ & $\begin{array}{r}12.5-15.0 \\
\times 5.0-5.8\end{array}$ & not studied & $\begin{array}{l}\text { protolichesterinic } \\
\text { acid }\end{array}$ \\
\hline $\begin{array}{l}\text { M. taitensis } \\
\text { sp. nov. }\end{array}$ & $\begin{array}{l}\text { whitish } \\
\text { green to }\end{array}$ & $\begin{array}{l}\text { warted- } \\
\text { areolate or }\end{array}$ & $\begin{array}{l}\text { cream white } \\
\text { or yellowish, } \\
\text { often with a }\end{array}$ & $\begin{array}{c}10.0-14.0 \\
\times 4.0-4.7(- \\
5.0), \text { often }\end{array}$ & $\begin{array}{c}\text { in } \\
\text { hymenium, }\end{array}$ & $\begin{array}{c}\text { methoxymicareic } \\
\text { acid }\end{array}$ \\
\hline
\end{tabular}




\begin{tabular}{|c|c|c|c|c|c|c|}
\hline & $\begin{array}{l}\text { bright } \\
\text { green }\end{array}$ & $\begin{array}{l}\text { sometimes } \\
\text { membranate }\end{array}$ & $\begin{array}{l}\text { greyish tinge } \\
\mathrm{K} \pm \text { violet, } \mathrm{C} \pm \\
\text { violet }\end{array}$ & $\begin{array}{l}\text { slightly } \\
\text { constricted } \\
\text { at the } \\
\text { septum }\end{array}$ & $\begin{array}{l}\text { sometimes } \\
\text { clustered }\end{array}$ & \\
\hline $\begin{array}{c}\text { M. } \\
\text { versicolor } \\
\text { sp. nov. }\end{array}$ & $\begin{array}{l}\text { whitish } \\
\text { green to } \\
\text { bright } \\
\text { green }\end{array}$ & $\begin{array}{l}\text { warted- } \\
\text { areolate or } \\
\text { continuous } \\
\text { crust, } \\
\text { sometimes } \\
\text { partly } \\
\text { granular and } \\
\text { then } \\
\text { composed of } \\
\text { goniocysts }\end{array}$ & $\begin{array}{l}\text { cream-white } \\
\text { to light grey } \\
\text { to dark } \\
\text { brownish- } \\
\text { grey or } \\
\text { blackish, if } \\
\text { pigmented } \\
\text { K+ } \\
\text { intensifying } \\
\text { purple and } \\
\text { K+ violet }\end{array}$ & $\begin{array}{c}9.5-13.0 \times \\
3.2-4.0(- \\
4.5)\end{array}$ & $\begin{array}{l}\text { in hymenium } \\
\text { and upper } \\
\text { part of } \\
\text { hypothecium }\end{array}$ & $\begin{array}{c}\text { methoxymicareic } \\
\text { acid }\end{array}$ \\
\hline
\end{tabular}




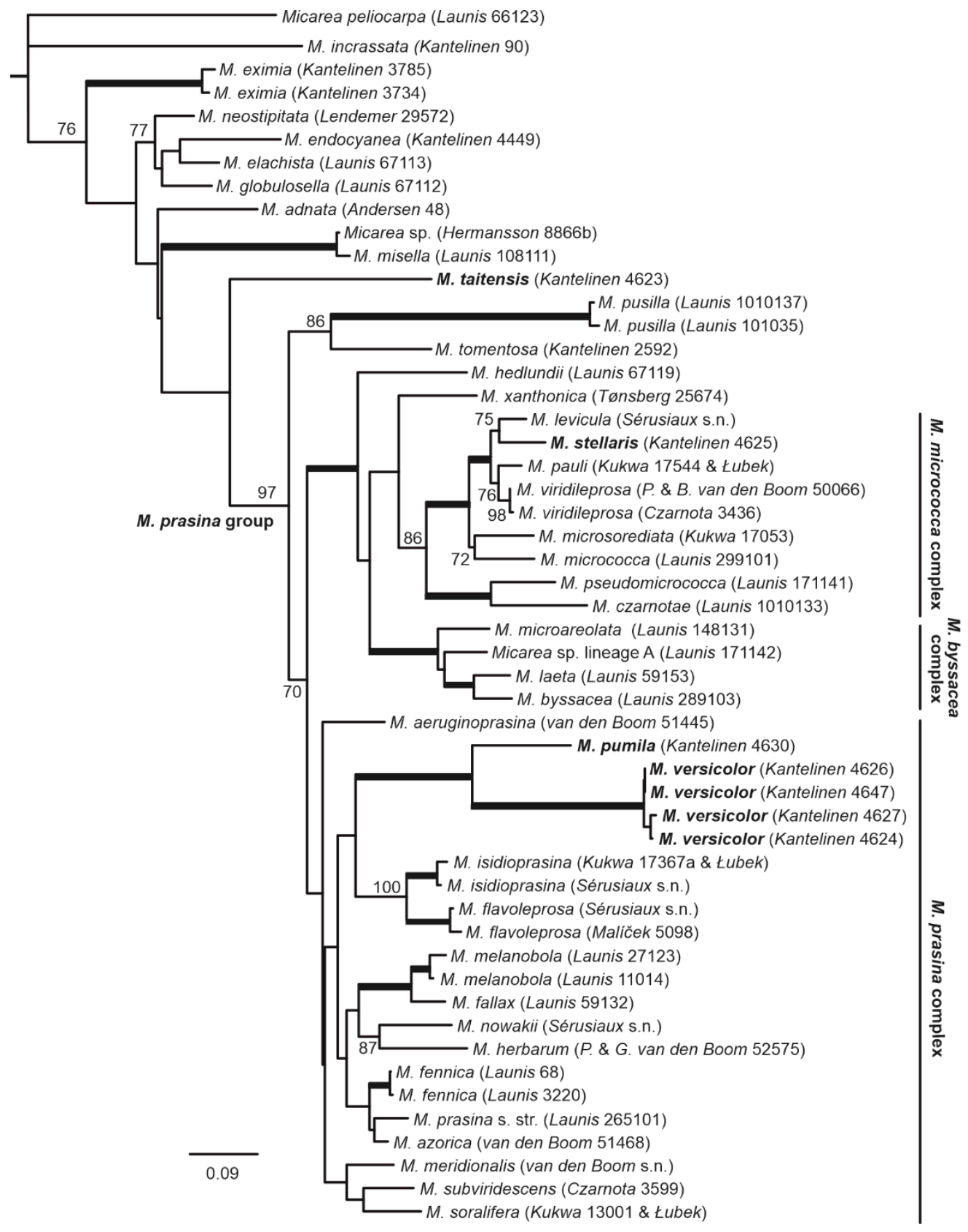

Fig. 1. Phylogenetic positions of Micarea pumila sp. nov., M. stellaris sp. nov., M. taitensis sp. nov. and $M$. versicolor sp. nov. (shown in bold) in a maximum likelihood phylogram obtained from the RAxML analysis (Stamatakis 2014) based on the combined ITS, mtSSU and Mcm7 data set. Branches supported with bootstrap values $\geq 70 \%$ in both analyses (RAxML and TNT (Goloboff $e t$ al. 2008)) are indicated in bold. Bootstrap values $\geq 70 \%$ supported only in the maximum likelihood analysis are shown above nodes. 


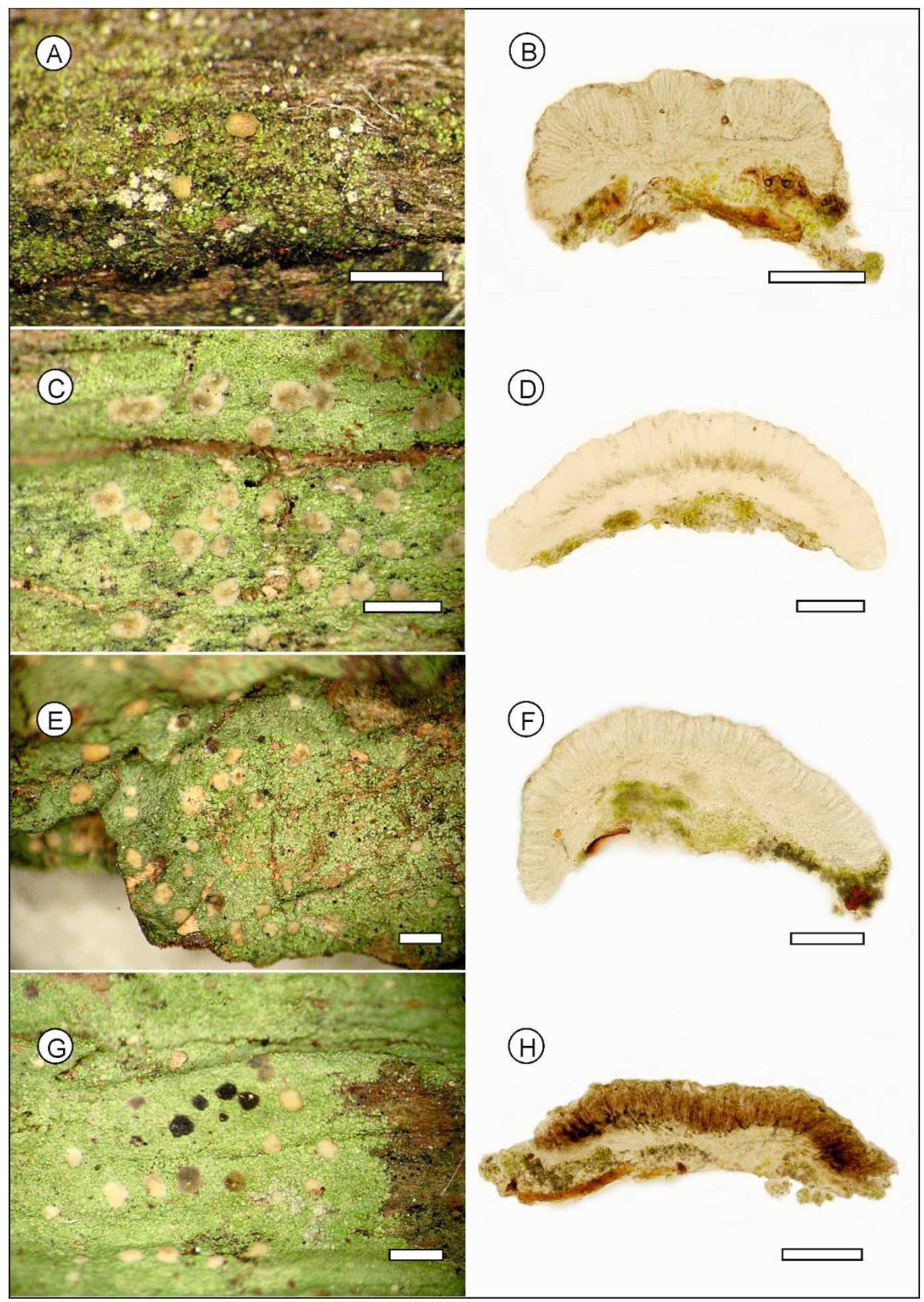

Fig. 2. Morphological and anatomical features. Micarea pumila (Kantelinen 4630, holotype, H): A, habit; B, apothecial section. Micarea stellaris (Kantelinen 4625, holotype, H): C, habit; D, apothecial section. Micarea taitensis (Kantelinen 4623, holotype, H): E, habit; F, apothecial section. Micarea versicolor (Kantelinen 4626, holotype, H): G, habit; H, apothecial section. Scales: A, C, E $\& \mathrm{G}=1 \mathrm{~mm} ; \mathrm{B}, \mathrm{D}, \mathrm{F} \& \mathrm{H}=100 \mu \mathrm{m}$. 


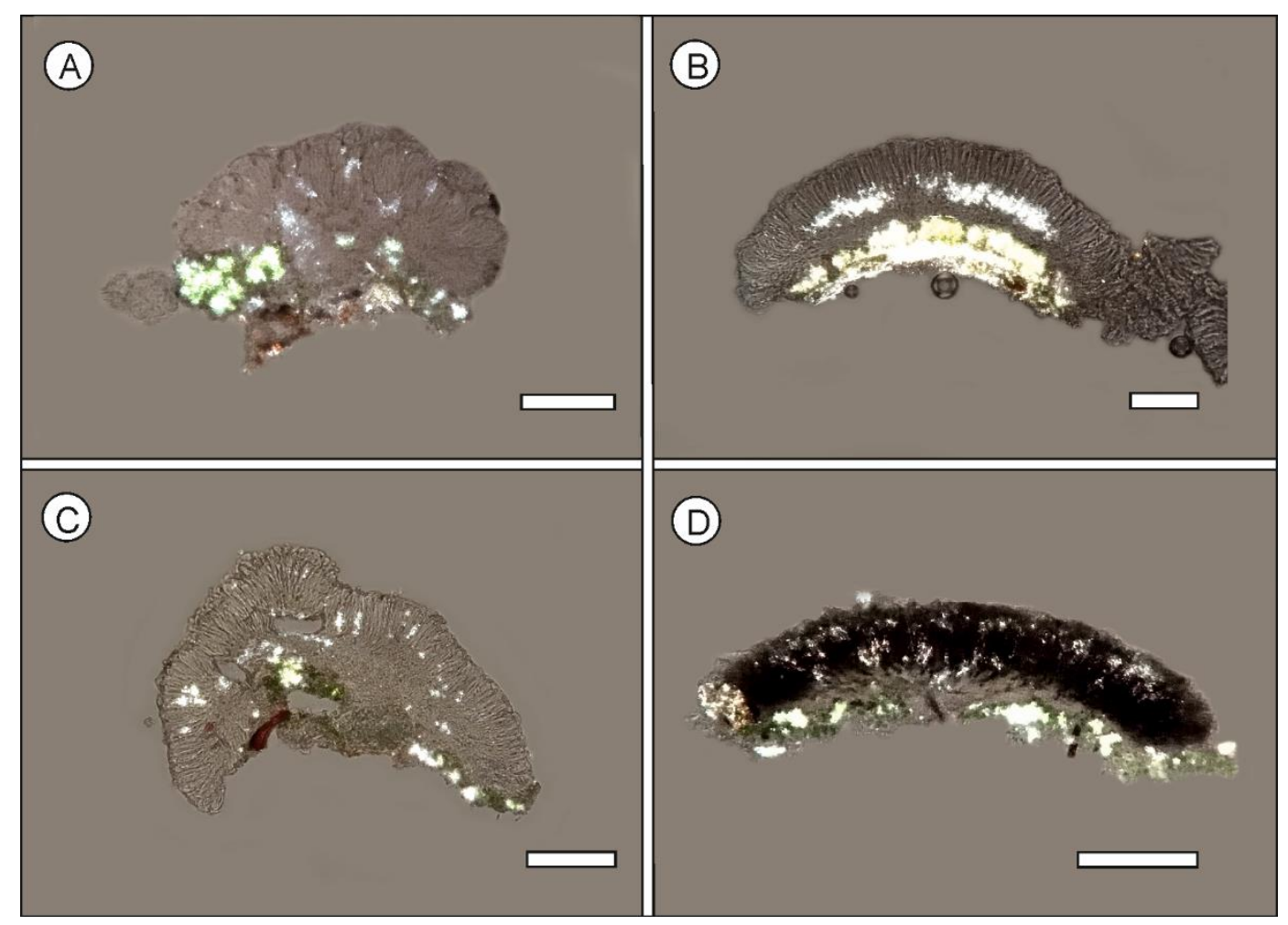

Fig. 3. Crystalline granules detected in apothecial sections in polarized light. A, Micarea pumila (Kantelinen 4630, holotype, H). B, Micarea stellaris (Kantelinen 4625, holotype, H). C, Micarea taitensis (Kantelinen 4623, holotype, H). D, Micarea versicolor (Kantelinen 4626, holotype, H). Scales $=100 \mu \mathrm{m}$. 

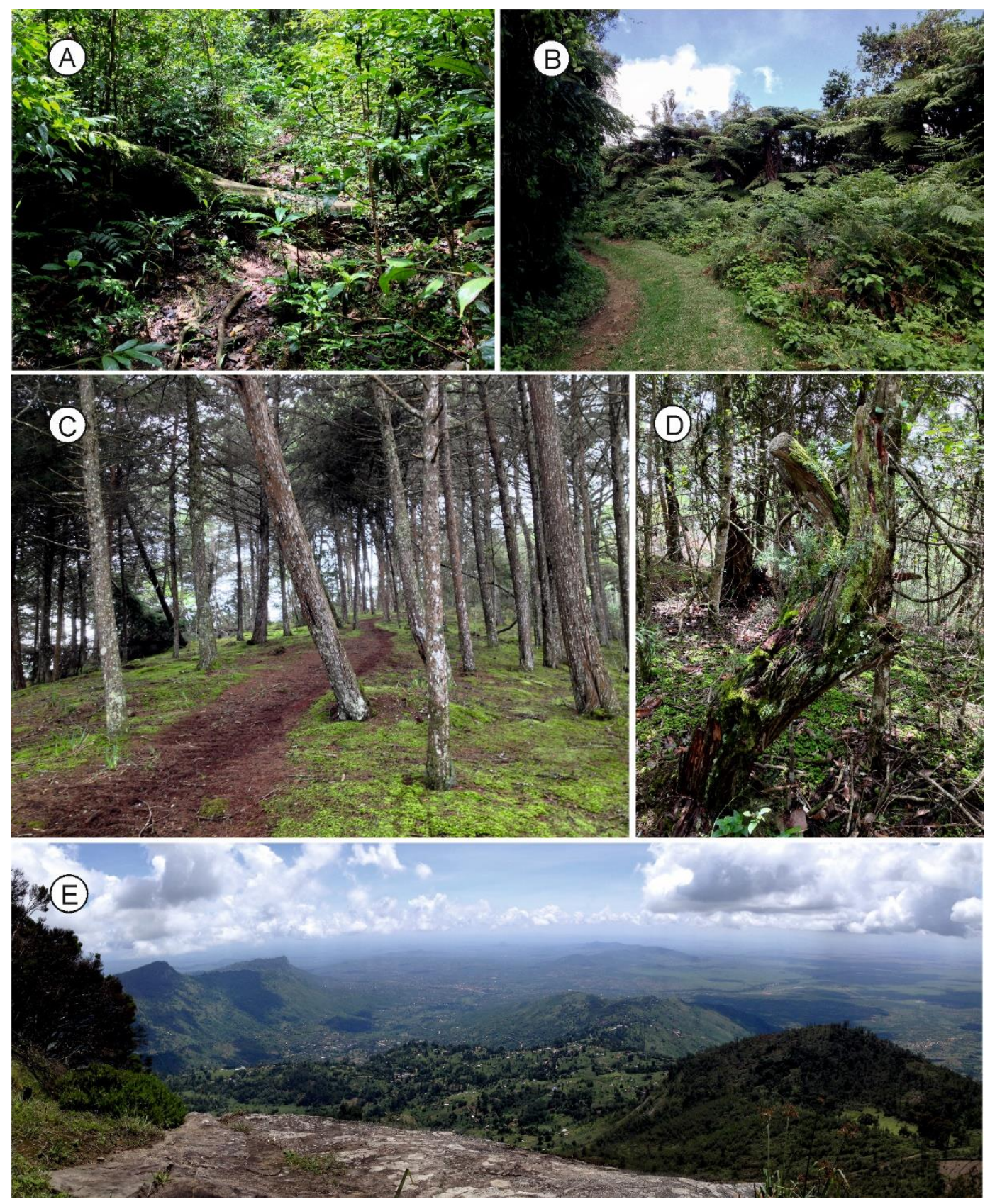

Fig. 4. Habitats. A, indigenous forest on Ngangao Mountain. B, indigenous forest on Vuria Mountain. C, Pinus patula plantation near top of Ngangao. D, collection site of M. pumila in the Pinus patula plantation. E, landscape seen from the top of Vuria (2228 $\mathrm{m}$ a.s.1.). 